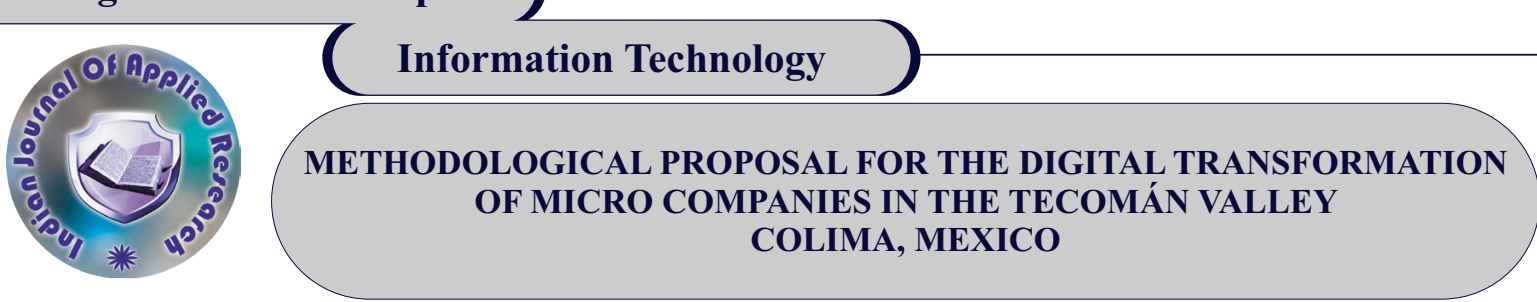

Oscar Mares

Banuelos

\title{
Arquímedes
}

Arcega Ponce*

\section{Enrique Macias}

Calleros

\section{Alfredo Salvador \\ Cardenas Villalpando}

University Of Colima, México, Accounting \& Management School of Tecomán.

University Of Colima, México, Accounting \& Management School of Tecomán. *Corresponding Author

University Of Colima, México, Accounting \& Management School of Tecomán. ABSTRACT

This research work describes the methodology used to manage a digital transformation center located in the Tecomán Valley, Colima, México, which involved actions of the triple helix management model. The phases deployed to materialize this long-term project that involves the participation of academia, the state and private initiatives are addressed. The results are the implementation of infrastructure to deploy industry 4.0 projects: IoT, cloud services and precision agriculture. In the current year 2020 , other IT services.

KEYWORDS : Industry 4.0, Digital transformation, Internet of things, Triple helix model.

\section{INTRODUCTION}

The research analyzes the initiative of the creation of the Digital Transformation Center in the Tecomán Valley, Colima, Mexico, under the triple helix and clustered project management model supported by the studies of Etzkowitz, L Leydesdorff (1990), Schumpeter J. (1934), ME Porter (1995), Peter Drucker (1998). In addition to the quality concepts analyzed by Jurán, Crosby, Deming, Ishikawa, Horovitz, Ruiz C., López J., Chiavenato. Under these approaches, and at the initiative of the IT Cluster Colima AC, in collaboration with the University of Colima and the H. City Council of the city of Tecomán, Colima, Mexico, the conception and creation of the Center is managed from 2019-2020 of Digital Transformation in this Valley. The participation of allies from the IT industry such as SigFox México and Clarion México stand out. The Tecomán Valley is one of the most important agricultural producers in Mexico (SIAP SAGARPA, 2017), with four product systems in the first places, and a gastronomic corridor of $5 \mathrm{~km}$ in the Mexican Pacific. According to the context described, it is essential to develop micro enterprises in the Tecomán Valley, through the transversal use of IT (OECD, 2018).

\section{METHODOLOGICALDESCRIPTION}

The proposed methodology aims to increase the productive capacities of companies ( $92 \%$ of the economic chain in the region: INEGI, 2017) and comprises the following phases: Phase I: a. The PMO (PMBOK: Project Office) is integrated, describe roles and functions $b$. The general description of the problem-project is built, according to user stories, SCRUM. b. By means of statistical selection techniques, prioritized strategic productive systems are determined, made up of economic units with homogeneous lines. Phase II: a. Meetings of members of the social and productive sector are held by unions, INEGI: common problems and solutions. b. A panel of the administrative economics, academic sector, IT companies and government authorities is formed as guarantors of transparency, forming an expert judgment based on the knowledge economy. Phase III: a. The solution is presented in a standardized document known as the Use Case, SCRUM, it is published and transparent according to the legislation in force in the country. The phases described are part of the global good practice methodologies, considering processes, products and services with adequate levels of the triple restriction Time, Cost, Scope: KPI, SLA and reasonable metrics or service agreements.

\section{TECHNIQUES}

The analysis applies a process of mixed information analysis approach: Quantitative: a. Standardized instruments applied to the unions of the micro companies. b. Documentary premises related to digital transformation. c. Statistical analysis of results. Qualitative: a.
Unstructured interview instrument with discourse-based analysis and triangulation of data.

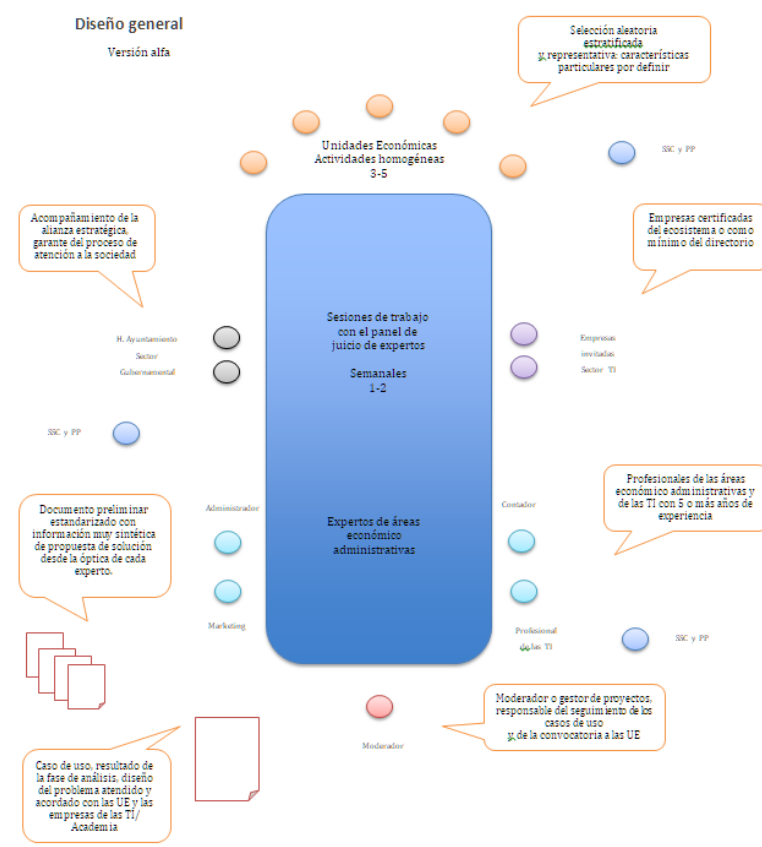

Figure 1: General Model Of ACTD

Sources: UCOL, own elaboration.

\section{TOOLSAND INFRASTRUCTURE}

The study seeks to increase the capacities of human capital related to digital transformation, for which innovative methodologies have been selected for their eventual implementation: PMBOK, ITIL, MoProSoft, TSP, SCRUM, COBIT and CMMI.

\section{CONCLUSIONS}

The Digital Transformation Centers are high-impact initiatives that facilitate the attraction of national and international public and private funds (AMITI, 2017-2020) to generate projects: Smart Cities, improvement of Public Services, (Cluster TI Colima AC, 2019), Digital Economy, Industry 4.0 or IoT, (IMCO, 2017-2020). Also of interest is the analysis of human resources and how they are trained 
through the nuclei of competence and professional profiles within the academy in order to assess whether these needs are sufficient for the demand of the labor, social and social market. productive (OECD-Pisa, 2018).

\section{REFERENCES:}

[1] Arana López, L M; Ruiz Rivera, M E; La Serna Palomino, N; (2015). Análisis de aplicaciones empleando la computación en la nube de tipo PaaS y la metodología ágil SCRUM. Industrial Data, 18() 149-160

[2] Calvo-Manzano, JA; Sánchez, A; Arcilla, M; Cerrada, C; San Feliu, T; Gómez, G; Ruiz, E; (2007). "Una propuesta organizativa de los procesos de SD y SS en ITIL. REICIS". Revista Española de Innovación, Calidad e Ingeniería del Software, 3() 6-20.

[3] Diez-Silva, H; Romero-Infante, J A; (2013). "Gestión de proyectos ecoturísticos orientados al mercado internacional con impacto en el desarrollo local mediante aplicación del estándar PMBOK $\mathbb{R}$ ”. Revista Escuela de Administración de Negocios, () 154-175.

[4] Okuda Benavides, M., \& Gómez-Restrepo, C. (2005). Métodos en investigación
cualitativa: triangulación. Revista Colombiana de Psiquiatría, XXXIV(1), 118-124. cualitativa: triangulación. Revista Colombiana de Psiquiatría, XXXIV (1), 118-124.

[5] Ramos, F; Torres, O; Sánchez, N; Alba, M; (2010). Implantación de CMMI nivel de madurez 2 en una PYME. REICIS. Revista Española de Innovación, Calidad e Ingeniería del Software, 6() 35-46.

[6] Sánchez Peña, J., \& Fernández Vicente, E., \& Moratilla Ocaña, A. (2013). ITIL, COBIT and EFQM: Can They Work Together? International Journal of Combinatorial Optimization Problems and Informatics, 4 (1), 54-64.

[7] Vargas Díaz, C. (2009). Transparencia de la información económico-financiera a través del e-gobierno o gobierno electrónico: caso español. Perspectivas, (24), 59-90. 